\title{
'We' is for Anarchism: Construction and Use of Collective Identity in the Anarchist Press of Fin-de-siècle Switzerland ${ }^{\mathrm{i}}$
}

\author{
Nino Kühnisi ${ }^{\text {ii }}$
}

\begin{abstract}
Despite strong statist and societal headwinds in late 19th and early 20th century, the anarchist movement in Switzerland persisted and for both seasoned and new activists, it remained an inviting and attractive movement to engage in. This paper brings to attention, that the permanent (re)constitution of collective identity played an integral part herein. As I shall contend, collective identity's dualistic character of simultaneous preservation and maintenance on one hand and of progress and development on the other, was key to the preservation of anarchism as a social movement in Switzerland. The analysis of 23 anarchist newspapers published between 1885 and 1914 in Switzerland in French and German discloses construction, use and embodiment of anarchist collective identity that are to be presented and discussed. In conclusion, light shall be shed on collective identity's role as a key motivational factor for social movements that focus on abstracta rather than on realia. [Article copies available for a fee from The Transformative Studies Institute. E-mail address: journal@transformativestudies.org

http://www.transformativestudies.org (C2012 by The Transformative Studies Institute. All rights reserved.]
\end{abstract}

KEYWORDS: Collective Identity, Anarchism, Fin-De-Siècle, Switzerland, Anarchist Media.

\footnotetext{
${ }^{\mathrm{i}}$ This article is the manuscript of a speech with the same title held on January 72012 at the 3rd Annual North American Anarchist Studies Network Conference in San Juan, Puerto Rico.

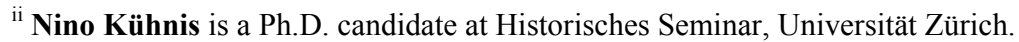
Acknowledgements: Many thanks to the organizing collective in San Juan and to Nathan Jun specifically for offering the opportunity to contribute to this issue of Theory In Action. Source for this speech is the research on the author's $\mathrm{PhD}$ thesis on anarchist collective identity occurring in anarchist and non-anarchist media in Switzerland 18851914. The author is holder of a scholarship from Fonds Forschung Ellen Rifkin Hill. Address correspondence to: Nino Kühnis, Historisches Seminar, Universität Zürich, KarlSchmid-Strasse 4, 8006 Zürich, Switzerland; e-mail: nino.kuehnis@uzh.ch.
} 